\title{
Tinjauan Normatif-Empiris Asas Partisipatif dalam Perencanaan Pembangunan Kota: Normalisasi Kali Ciliwung di Bukit Duri
}

\author{
Vera Wheni S. Soemarwi \\ Jurusan Fakultas Hukum, Universitas Tarumanagara \\ Email: veras@fh.untar.ac.id
}

\begin{abstract}
ABSTRAK
Para penyelenggara negara yang menjalankan fungsi eksekutif dibatasi dalam setiap keputusan hukum dan tindakan faktual harus berdasarkan pada hukum (Undang-Undang Dasar Negara Republik Indonesia Tahun 1945, Pasal 1 ayat (3)). Sumber hukum yang digunakan bersumber pada peraturan perundang-undangan, kebiasaan, dan putusan pengadilan. Kewenangan pejabat pemerintah dibatasi dengan peraturan perundang-undangan dan asasasas umum pemerintahan yang baik (AUPB)(Undang-Undang Republik Indonesia Nomor 30 Tahun 2014 Tentang Administrasi Pemerintahan, Pasal 8 ayat (2)). Pejabat pemerintah dalam merumuskan, merencanakan, melaksanakan dan mengevaluasi kebijakan wajib melibatkan partisipasi masyarakat. Karena partisipasi masyarakat merupakan perwujudan dari negara demokrasi dan kedaulatan negara tertinggi berada pada masyarakat. Prinsip dasar partisipasi diadopsi dalamsetiap asas yang diatur dalam AUPB.Penyelenggara negara dalam menentukan dan melaksanakan kebijakan program pembangunan wajib dilakukan dan ditentukan berdasarkan peraturan perundang-undangan, prinsip-prinsip tata kelola pemerintahan yang baik, dan penghormatan hak warga secara luas termasuk hak atas lingkungan.Fokus penelitian ini adalah bagaimana pengelolaan pembangunan kota dilakukan dengan tetap memperhatikan prinsip tata kelola pemerintahan yang baik dan melibatkan masyarakat.Dalam menyampaikan karya ilmiah ini, penulis menggunakan metode penelitian normatif-empiris. Permasalahan utama yang diangkat dalam penelitian ini: pentingkah penerapan asas partisipasi yang merupakan bagian dariasas-asas umum pemerintahan yang baik dalam perencanaan pembangunan kota?
\end{abstract}

Kata kunci: tata kelola pemerintahan yang baik; pembangunan untuk kepentingan umum; tata kelola pemerintahan dalam pembangunan.

\section{PENDAHULUAN}

Konsep bernegara perlu dipertegas kembali. Khususnya mengenai definisi apa itu negara? Apakah penyelenggara negara dapat mengatasnamakan negara untuk melaksanakan perbuatan yang melawan hukum? Untuk menjawab pertanyaan tersebut Penulis akan mengkaji apa itu definisi negara menurut ahli dan bagaimana konstitusi mengatur mengenai dasar negara itu?

CF. Birch memaknai negara sebagai sebuah organisasi yang mempunyai dua sendi pokok yang perlu diperhatikan. Sendi pertama yaitu sendi kekuasaan. Sendi kedua yang penting adalah proses penyatuan atau integrasi dari masyarakat-masyarakat untuk membentuk sebuah organisasi yang disebut negara. Bila masyarakat tidak bisa bersinergi dan bersatu maka sulit bagi bangsa untuk membentuk negara demokratis yang ideal. Proses integrasi masyarakat dapat dilakukan melalui proses integrasi nasional. Sebuah proses menyatukan kelompok-kelompok masyarakat dalam bidang politik-historis, sosio-kultural, interaksi (transportasi-komunikasi) dan ekonomis, sehingga menjadi kelompok nasional dari kelompok-kelompok daerah (regional)(Suwarno, 1994)

Proses penyempurnaan Bangsa Indonesia menjadi negara hukum yang demokratis telah dilakukan melalui perubahan Undang-Undang Dasar Negara Republik Indonesia Tahun 1945 (selanjutnya disingkat UUD NRI 1945).Perubahan UUD NRI 1945 berusaha untuk mengakomodasi prinsip-prinsip negara demokrasi. Teori substansi konstitusi menurut B Hestu Cipto Handoyo mengatur mengenai (1) terjaminnya perlindungan hak asasi manusia; (2) pemisahan kekuasaan yang tegas; (3) legalitas pemerintahan; dan (4) peradilan yang bebas (Handoyo, 2009). 
Sejak konstitusi diamandemen sistem negara dan tata kelola pemerintahan (good governance) telah diubah. Perubahan itu kearah kepastian akan penerapan asas-asas dalam setiap kebijakan tata usaha negara [selanjutnya disingkat dengan TUN]. Pentingnya penerapan asas-asas umum pemerintahan yang baik(selanjutnya disingkat AUPB) sebagai tolok ukur dalam menilai setiap kebijakan TUN menjadi jelas dan terukur.

Definisi negara hukum menurut krabe:

"Negara sebagai pencipta dan penegak hukum di dalam segala kegiatannya harus tunduk pada hukum yang berlaku. Dalam arti ini hukum membawahkan negara. Berdasarkan pengertian hukum itu bersumber dari kesadaran hukum rakyat maka hukum mempunyai wibawa yang tidak berkaitan dengan seseorang." (Ranawijaya, 1983).

Good governance penting dilaksanakan oleh pejabat pemerintah baik pusat maupun daerah dalam menjalankan fungsi sebagai penyelenggara pemerintahannya. Pembagian tugas-tugas pejabat pemerintah diatur dalam Undang-Undang Republik Indonesia Nomor 23 Tahun 2014 tentang Pemerintahan Daerah (Undang-Undang Republik Indonesia Nomor 23 Tahun 2014). Pembagian tugas dan kewenangan antara pemerintah pusat dan daerah secara tegas dibedakan berdasarkan urusan pemerintahan absolut, konkuren dan urusan pemerintahan umum. Pembagian tugas dan kewenangan dalam menjalankan fungsi pemerintahannya dilaksanakan berdasarkan asas desentralisasi, dekonsentrasi, dan tugas pembantuan.

Dalam penelitian ini, penulis akan membahas mengenai tugas dan fungsi pemerintah dalam (1) perencanaan dan pengendalian pembangunan;dan (2) perencanaan, pemanfaatan, dan pengawasan tata ruang. Gambaran khusus mengenai penjabaran tugas pejabat pemerintah tersebut, Penulis menggunakan program Normalisasi Kali Ciliwung dengan tetap memperhatikan bidang tugas lainnya yaitu bidang pengendalian lingkungan hidup.

Pejabat pemerintah dalam menjalankan setiap kewenangan termasuk menjalankan kedua tugas dan fungsi tersebut wajib dilaksanakan dengan mengacu pada prinsip good governance. Bila pejabat pemerintah dalam membuat keputusan melanggar salah satu dari ketiga prinsip good governance akan berdampak pada batalnya keputusan hukum dan faktual. Pembatalan keputusan tersebut harus dimohonkan melalui Pengadilan Tata Usaha Negara.

Pembahasan selanjutnya akan disampaikan mengenai bagaimana perencanaan dan pelaksanaan program pembangunan nasional? Apakah perencanaan dan pelaksanaan program pembangunan sudah sesuai dengan prinsip good governance?

\section{METODE PENELITIAN}

Dalam penelitian ini, Penulis menggunakan metode penelitian normatif-empiris. Penulis menentukan obyek penelitian ini adalah program Normalisasi Kali Ciliwung di RW. 10, 11 dan 12, Kelurahan Bukit Duri, Kecamatan Tebet, wilayah Administrasi Kota Jakarta Selatan.Data kualitatif dan kuantitatif yang disajikan oleh Penulis dalam penelitian ini mengenai perencanaan dan pelaksanaan proyek Normalisasi Kali Ciliwung serta status tanah-tanah disekitar wilayah RW. 10, 11, dan 12 diperoleh Penulis dari proses wawancara kepada 94 warga terdampak program Normalisasi Kali Ciliwung yang tinggal di wilayah RW. 10, 11, dan 12. Penelitian ini dilakukan sejak bulan Januari tahun 2015.

Penulis menggunakan sumber data primer dan sekunder dalam penelitian ini. Sumber data primer yaitu data yang langsung dikumpulkan oleh peneliti dari sumber pertamanya. Sumber data primer dalam penelitian ini adalah peraturan perundang-undangan; kebijakan tertulis 
maupun tidak tertulis dari Gubernur DKI Jakarta periode 2014 - 2017, Ketua Pengurus Yayasan Ciliwung Merdeka; data kepemilikan tanah, status bangunan, proses keterlibatan para penggugat dalam gugatan perwakilan kelompok Bukit Duri (warga terdampak penggusuran di RW. 10, 11, dan 12).

Penulis menggunakan sumber data skunder dalam penelitian ini. Dalam penelitian ini, dokumentasi dan angket merupakan sumber data sekunder.Teknik pengumpulan data yang digunakan oleh Penulis dalam penelitian ini adalah (1) metode observasi; (2) metode interview; dan (3) metode dokumentasi.

\section{PERMASALAHAN HUKUM}

1. Bagaimana pejabat pemerintah memaknai asas partisipasi masyarakat dalam perencanaan pembangunan kota?

2. Bagaimana dampak yang terjadi pada masyarakat bila asas partisipasi dan good governance tidak diterapkan dalam perencanaan dan pelaksanaan pembangunan kota?

\section{GOOD GOVERNANCE}

Konsep negara yang dianut oleh Bangsa Indonesia adalah organisasi kekuasaan masyarakat. Konsep ini tercermin dalam kedaulatan yang dinyatakan secara tegas dalam Konstitusi NRI 1945 yaitu kedaulatan ada pada rakyat. Perubahan yang mendasar setelah konstitusi diamandemen, kedaulatan Bangsa Indonesia adalah kedaulatan hukum dan kedaulatan tertinggi ada pada masyarakat Indonesia. Kedua kedaulatan ini harus dimaknai bahwa seluruh kebijakan yang dibuat oleh penyelenggara negara harus melibatkan partisipasi masyarakat. Kunci utama dalam penyelenggaraan negara oleh Pemerintah Indonesia wajib mengajak partisipasi masyarakat dalam setiap perumusan, pelaksanaan dan pemantauan kegiatan pemerintahan. Bila masyarakat tidak menghendaki kebijakan tersebut maka penyelenggara negara tidak bisa melaksanakan kebijakan tersebut.

The United Nations Commission on Human Rights merumuskan good governance adalah "proses dimana lembaga-lembaga publik melakukan urusan publik, mengelola sumber daya publik dan menjamin realisasi hak asasi manusia dengan cara yang pada dasarnya bebas dari penyalahgunaan dan korupsi dan dengan memperhatikan aturan hukum"(United Nations Commission on Human Rights).

Tolok ukur dalam penilaian pelaksanaan tata kelola pemerintahan yang baik adalah sejauh mana keputusan penyelenggara pemerintah dapat memenuhi perlindungan dan pemenuhan hak-hak manusia: hak sipil, hak budaya, hak politik, hak ekonomi, hak sosial, hak atas kesehatan, hak atas perumahan yang layak, makanan yang cukup, kualitas pendidikan, peradilan yang adil, keamanan pribadi dan jaminan kepastian atas hak milik.

Pejabat pemerintah tidak boleh mengabaikan prinsip-prinsip dalam good governance dengan alasan demi kemanfaatan umum. Karena pertimbangan kemanfaatan umum atas suatu keputusan dan/atau tindakan tidak boleh melanggar norma-norma agama, sosial dan kesusilaan. Kemanfaatan umum harus dijalankan dan memberikan dampak positif pada peningkatan kesejahteraan dan kepentingan seluruh warga(Pasal 9 ayat (4) UU No. 30/2014).

Pertanyaannya warga yang mana yang perlu dilibatkan atau berpartisipasi dalam seluruh proses itu? Warga masyarakat yang utama perlu dilibatkan dan berpartisipasi secara aktif adalah seseorang atau badan hukum perdata yang terkait langsung dengan keputusan dan/atau tindakan pejabat pemerintah di wilayahnya(Pasal 1, UU No. 20/2014). 
Pertanyaan mendasar sudahkan pejabat pemerintah melaksanakan prinsip-prinsip utama good governance dalam pelaksanaan program Normalisasi Kali Ciliwung di wilayah RW. 10, 11, dan 12, Kelurahan Bukit Duri, Kecamatan Tebet, Jakarta Selatan?

\section{PERENCANAAN PEMBANGUNAN dan PENATAAN KOTA JAKARTA}

1. Perencanaan Program Pembangunan

Sistem perencanaan pembangunan di tingkat nasional yang diterapkan oleh Bappenas ini masih sangat kental dengan pendekatan politik. Proses perencanaan dengan pendekatan politik ditinjau dari proses gagasan itu timbul sampai pada penetapan perencanaan program pembangunan.Karena sistem perencanaan ini tidak digagas dan direncanakan bersama-sama dengan masyarakat.

Menteri Negara Perencanaan Pembangunan Nasional/Kepala Bappenas,Bapak H. Paskah Suzetta pada tanggal 22 Maret 2007 menegaskan mengenai proses teknokratik menghapuskan elemen partisipasi masyarakat dalam proses perencanaan pembangunan nasional. Menteri Bapenas beranggapan partisipasi masyarakat dalam memilih preferensi atau keinginan dan harapan masyarakat dalam menentukan program pembangunan memerlukan proses yang panjang, tenaga, dan biaya yang tinggi. Beliau beranggapan proses "partisipasi masyarakat kurang praktis". Sehingga partisipasi publik diganti dengan proses politik(www.setneg.go.id).

Menurut Bapak Paskah Suzetta proses teknokratik ini dianggap sudah memadahi. Karena perumusan kebutuhan pembangunan dilakukan oleh para tenaga professional yang terdidik yang mampu merumuskan kebutuhan masyarakat disekitar wilayah itu.

Dampak dari perencanaan pembangunan di tingkat nasional dan daerah memerlukan tanah-tanah dan penataan ruang untuk melaksanakan pembangunan tersebut. Ruang-ruang dan tanah-tanah di perkotaan sudah tidak mampu menyediakan lahan dan ruang untuk pembangunan. Tanah-tanah di perkotaan sudah dipadati oleh penduduk. Oleh karena itu untuk melaksanakan pembangunan tersebut, pemerintah perlu melakukan perencanaan kota dengan melibatkan partisipasi masyarakat secara aktif.

United Nation Habitat (selanjutnya disingkat UN Habitat) telah mengeluarkan Panduan Internasional Tentang Perencanaan Kota dan Wilayah. UN Habitat menetapkan prinsip-prinsip good governance dalam kebijakan penataan kota yaitu: “(1) perencanaan kota dan wilayah lebih dari sekedar alat teknis, ini adalah proses pengambilan keputusan yang integrative dan partisipatif membahas persaingan kepentingan dan terkait dengan visi bersama, strategi pembangunan secara keseluruhan dan kebijakan perkotaan nasional, regional dan lokal. (2) Perencanaan kota dan wilayah merupakan komponen inti dari paradigm tata kelola pemerintahan kota yang baru, yaitu mempromosikan demokrasi lokal, partisipasi dan inklusi, transparansi dan akuntabilitas dengan maksud untuk menjamin urbanisasi berkelanjutan dan kualitas tata ruang.

Prinsip pembangunan yang berkelanjutan menurut UN Habitat harus memperhatikan tiga dimensi yaitu pembangunan sosial dan inklusi, pertumbuhan ekonomi yang berlanjut, serta perlindungan dan pengelolaan lingkungan. Untuk mencapaiketiga dimensi itu diperlukan komitmen politik dan komitmen seluruh pemangku kepentingan bangsa termasuk masyarakat untuk berpartisipasi dalam proses perencanaan kota dan wilayah.

Proses perencanaan pembangunan ini akan berdampak pada penganggaran. Melihat pada skema yang dilaksanakan oleh Bappenas, timbul beberapa kendala seperti: (1) lemahnya kordinasi 
dalam pengelolaandata dan informasi sehingga penentuan program pembangunan seringkali tidak tepat sasaran. (2) Lemahnya keterkaitan proses perencanaan, proses penganggaran dan proses politik dalam menerjemahkan dokumen perencanaan menjadi dokumen anggaran. (3) Kurangnya keterlibatan masyarakat sebagai pemangku kepentingan yang utama dalam pembangunan. (4) Lemahnya sistem pemantauan, evaluasi dan pengendali. (5) Lemahnya kordinasi antara pemerintah pusat dan pemerintah daerah(www.setneg.go.id).

2. Pelaksanaan program Normalisasi Kali Ciliwung sebagai program pembangunan nasional.

Penentuan program Normalisasi Kali Ciliwung dilaksanakan sebagai program pembangunan nasional melalui proses teknokratik. Ketika program ini ditentukan oleh pemerintah pusat tidak melibatkan masyarakat terdampak. Penentuan perencanaan program Normalisasi Kali Ciliwung dalam bentuk pemasangan beton-beton (sheet pile) di tepi-tepi Kali Ciliwung dan pembangunan jalan inspeksi di sekitar Kali Ciliwung sebagai program yang dapat menanggulangi banjir di wilayah Jakarta sudah tepat? Perencanaan program ini belum dilakukan melalui (1) proses analisis dampak lingkungan dan (2) melibatkan partisipasi seluruh elemen masyarakat khususnya masyarakat terdampak. Bagaimana dampak pada masyarakat bila kedua proses ini tidak dilaksanakan?

Masyarakat tidak mengetahui rencana pejabat pemerintah akan melaksanakan program Normalisasi Kali Ciliwung. Meskipun program ini ditandatangani pada tanggal 12 Januari 2012dan diatur dalam Peraturan Daerah DKI Jakarta No. 1 Tahun 2012 Tentang Rencana Tata Ruang Wilayah 2030 (untuk selanjutnya disebut sebagai Perda No. 1/2012) Tabel 6 point 3.3 .4 dan point 3.3.6.

Kemudian pada tanggal 28 September 2012, Pemerintah DKI Jakarta saat itu merencanakan program ini dan mengaturnya dalam Peraturan Gubernur No. 163 Tahun 2012 Tentang Penguasaan Perencanaan/Peruntukan Tanah Bagi Pelaksanaan Pembangunan Untuk Kepentingan Umum Rencana Trace Kali Ciliwung Dari Pintu Air Manggarai-Kampung Melayu[selanjutnya disingkat dengan Pergub No. 163/2012]. Salah satu dasar hukum yang digunakan dalam Pergub ini adalah Undang-Undang No. 2 Tahun 2012 Tentang Pengadaan Tanah Bagi Pembangunan Untuk Kepentingan Umum(untuk selanjutnya disebut sebagai UU No. 2/2012). Peraturan Presiden Republik Indonesia No. 71 Tahun 2012 Tentang Penyelenggaraan Pengadaan Tanah Bagi Pembangunan Untuk Kepentingan Umum (untuk selanjutnya disebut sebagai Perpres No. 71/2012). Kewajiban Pemerintah Provinsi DKI Jakarta untuk membebaskan tanah-tanah milik warga masyarakat yang akan digunakan untuk program Normalisasi Kali Ciliwung berdasarkan UU No. 2/2012 jo. Perpres No. 71/2012 tertuang dalam Dokumen Amdal Proyek Normalisasi Kali Ciliwung dan RKL serta RPL.

Tujuan pembangunan dilaksanakan untuk mencapai masyarakat yang adil, makmur, dan sejahtera dapatterwujud.Pembangunan untuk kepentingan umum harus dilaksanakan dengan prinsip kemanusiaan, keadilan, kemanfaatan, kepastian, keterbukaan, kesepakatan, keikutsertaan, kesejahteraan, keberlanjutan, dan keselarasan. Prinsip-prinsip tersebut terkandung dalam UUDNRI Tahun 1945 dan hukum tanah nasional (Undang-Undang Pokok Agraria/UUPA). Pembangunan demi kepentingan umum yang dilakukan oleh pemerintah memerlukan tanahtanah bagaimana program pembangunan ini tetap dilaksanakan tanpa mengorbankan warga masyarakatnya. Karena kebanyakan tanah-tanah di Indonesia sudah dimiliki oleh masyarakat.

Masyarakat terdampak tidak pernah dilibatkan dalam proses perencanaan dan pelaksanaan program Normalisasi Kali Ciliwung. Masyarakat mengetahui program ini akan diterapkan 
melalui proses sosialisasi yang dilakukan oleh pejabat pemerintah setempat. Sosialisasi pernah dilakukan empat (4) $\mathrm{kali}^{1}$ khusus bagi warga masyarakat di wilayah RW. 10, 11, dan 12, Kelurahan Bukit Duri, Tebet, Jakarta Selatan. Pada sosialisasi pertama yang dilakukan oleh Gubernur DKI Jakarta, Joko Widodo, pada tanggal 16 Oktober 2012, Gubernur saat itu menanyakan tentang apa keinginan warga terdampak bila tanah dan rumahnya akan dikenakan program normalisasi? Saat itu aspirasi warga mengatakan keinginan untuk mendapatkan penggantian berupa permukiman baru dalam wujud Kampung Susun Manusiawi Bukit Duri. Warga terdampak tidak ingin direlokasi ke tempat yang jauh dari lokasi awal. Gubernur Jokowi menyanggupi untuk memenuhi aspirasi tersebut.

Setelah Jokowi digantikan dengan Gubernur DKI Jakarta periode 2014-2017 pola sosialisasi berubah. Janji Jokowi yang akan mewujudkan Kampung Susun (Pak Jokowi lebih suka menggunakan istilah "kampung Deret"), berubah. Gubernur periode 2014-2017 mengubah sistem pengadaan tanah dengan konsep ganti untung menjadi tanpa ada ganti rugi. Perubahan sistem dari pengadaan tanah menjadi pemberian hak sewa di unit Rumah Susun Sewa (Rusunawa) dilakukan secara sepihak. Perubahan kebijakan pejabat daerah ini tidak dituangkan dalam bentuk peraturan tertulis.

Pejabat pemerintah sudah tidak mempunyai wewenang yang timbul berdasarkan Pergub DKI Jakarta No. 163/2012 jo Kepgub DKI Jakarta No. 2181/2012. Wewenang pejabat pemerintah berdasarkan kedua peraturan itu sudah daluarsa sejak 5 Oktober 2015.

Pejabat pelaksana program Normalisasi Kali Ciliwung mengetahui bahwa para pejabat pemerintah sudah tidak mempunyai kewenangan lagi. Namun para pejabat pemerintah tetap melaksanakan program ini. Para pejabat pemerintah menggusur warga di pinggir kali dengan cara melawan hukum (Putusan No. 205/G/2016/PTUN-JKT). Pejabat pemerintah itu tidak melaksanakan kewajiban yang timbul berdasarkan Ijin Lingkungan (Izin Lingkungan No.: 15/7.1/31/1.774.1/2015) dan Ijin Kelayakan Lingkungan (Kelayakan Lingkungan Hidup Rencana Kegiatan Normalisasi Kali Ciliwung No.: 15/7.4/31/1.774.1/2015 Keputusan Kepala Badan Pelayanan Terpadu Satu Pintu Provinsi DKI Jakarta) yang diterbitkan oleh Pemerintah Provinsi DKI Jakarta serta Dokumen Analisis Dampak Lingkungan yang diterbitkan oleh Kementerian Pekerjaan Umum dan Perumahan Rakyat, Balai Besar Wilayah Sungai Ciliwung Cisadane pada bulan Maret 2015.

Dampak dari penggusuran yang dilakukan secara melawan hukum oleh pejabat pemerintah dengan menggunakan aparat gabungan dan perangkat senjata itu, sejumlah 4.387 orang yang tinggal di wilayah Bukit Duri kehilangan tempat tinggal, kehilangan tanah, dan tempat usahanya.

Sudargo Gautama berpendapat mengenai tugas pemerintah menurut konsep negara hukum kesejahteraan adalah:

"Negara hukum yang modern dianggap mempunyai kewajiban yang lebih luas. Negara yang modern harus mengutamakan kepentingan seluruh masyarakat. Kemakmuran dan keamanan sosial bukan hanya keamanan senjata yang harus dikejar. Kemakmuran seluruh lapisan masyarakat yang harus dicapai. Berdasarkan tugas pemerintah ini, maka penguasa jaman

\footnotetext{
${ }^{1}$ Sosialisasi Pertama pada tanggal 16 Oktober 2012 Gubernur DKI Jakarta Jokowi datang bersama Walikota Jakarta Selatan, Camat Tebet, Lurah Bukit Duri, dan BBWSCC. Sosialisasi kedua pada bulan Maret 2016. Sosialisasi ketiga pada bulan April 2016. Sosialisasi keempat pada bulan Juni 2016.
} 
sekarang turut serta aktif dalam mengatur pergaulan hidup dari khalayak ramai. Lapangan kerja penguasa pada waktu ini jauh lebih besar daripada pemerintah model kuno"(Gautama, 1983).

\section{KESIMPULAN}

Ilustrasi proses perencanaan pembangunan nasional berupa program Normalisasi Kali Ciliwung yang dilakukan (1) tanpa menerapkan prinsip-prinsip good governance, (2) tanpa melibatkan masyarakat terdampak, dan (3) sebelum proses perencanaan belum dilakukan analisis dampak lingkungan dan apa faktor-faktor penyebab banjir?

Prinsip-prinsip good governance dalam pelaksanaan program Normalisasi Kali Ciliwung tidak dilaksanakan. Prinsip yang dilanggar pertama adalah prinsip legalitas. Pejabat pelaksana program Normalisasi Kali Ciliwung mengetahui bahwa instansinya sudah tidak mempunyai wewenang untuk melaksanakan proyek itu namun pejabat pemerintah itu tetap melaksanakannya. Tindakan pejabat pelaksana proyek sangat bertentangan dengan prinsip negara demokrasi yang berdasarkan pada kedaulatan hukum.

Prinsip good governance yang kedua adalah penghormatan dan perlindungan terhadap hak asasi warga negaranya. Warga terdampak telah kehilangan tanah dan rumah. Warga terdampak kehilangan pekerjaan. Warga terdampak mengalami penurunan kondisi ekonomi dan kemerosotan kualitas hidup.

Prinsip doktrin AUPB yang belum dilaksanakan oleh Pejabat Pemerintah Pusat dan Daerah Provinsi DKI Jakarta yaitu (1) asas kepastian hukum; (2) asas kepentingan umum; (3)asas keterbukaan; (4) asas profesionalitas; (5) asas kemanfaatan; (6) asas ketidakberpihakan; dan (7) asas pelayanan yang baik.

Sejak proyek ini dirumuskan sampai pada pelaksanaannya, pejabat pelaksana proyek normalisasi tidak menempatkan masyarakat pada sentral kebijakan dengan cara mengikutsertakan warga terdampak yaitu warga Bukit Duri dalam setiap kebijakan pelaksanaan proyek.

\section{REFERENSI}

Adelman, I. (1999, May).The Role of Government in Economic Development, Working paper No. 890, Department of Agriculture and Resource Economics and Policy, University of California at Berkeley, California Agriculture Experiment Station.

Alexander, E. R. Why planning vs. markets is an Oxymoron: Asking the right question, Planning \& Markets, University of Southern California, Los Angeles, http://www-pam.usc.edu.

Christopher J Webster C. J. (1997, September 23).Analytical public choice planning theory. Submitted to TPR September 23rd 1997.

Conyers, D. \& Hills, P. (1990).An introduction to development planning in the third world.New York, NY: John Wiley \& Sons.

Dokumen Analisis Dampak Lingkungan Proyek Normalisasi Kali Ciliwung, Kementerian Pekerjaan Umum dan Perumahan Rakyat, Balai Besar Wilayah Sungai Ciliwung Cisadane, Maret 2015.

Gautama, S. (1983). Pengertian tentang negara hukum. Bandung: Alumni.

Handoyo, B. H. C. (2009). Hukum Tata Negara Indonesia, hal. 55-58.

Izin Lingkungan No.: 15/7.1/31/1.774.1/2015 dari Keputusan Kepala Badan Pelayanan Terpadu Satu Pintu Provinsi DKI Jakarta, Noor Syamsu Hidayat. 
Kelayakan Lingkungan Hidup Rencana Kegiatan Normalisasi Kali Ciliwung No.: 15/7.4/31/1.774.1/2015 Keputusan Kepala Badan Pelayanan Terpadu Satu Pintu Provinsi DKI Jakarta.

Peraturan Daerah Khusus Ibukota Jakarta Nomor 1 Tahun 2012 Tentang Rencana Tata Ruang Wilayah 2030.

Peraturan Gubernur Daerah Khusus Ibukota Jakarta Nomor 163 Tahun 2012 Tentang Penguasaan Perencanaan/Peruntukan Tanah Bagi Pelaksanaan Pembangunan Untuk Kepentingan Umum Rencana Trace Kali Ciliwung Dari Pintu Air Manggarai-Kampung Melayu.

Putusan No. 205/G/2016/PTUN-JKT.

Ranawijaya, U. (1983). Hukum Tata Negara Dasar-Dasarnya. Jakarta: Ghalia Indonesia, hal. 181.

Rondinelli, D. A. dan Cheema, G.S. (1983). Decentralization and Development: Policy Implementation in Developing Countries.London: Sage Publications.

Smith, B.C. (1985). Decentralization: The Territorial Dimension of the State. London: George Allen \& Unwin.

Sudjatmoko (2001,Oktober). Pembangunan Ekonomi Sebagai Masalah Budaya, dalam Muhidin M. Dahlan (Editor), Kebudayaan Sosialis, Kumpulan Tulisan Diterbitkan Dalam Rangka Mengenang 12 Tahun Wafatnya Raksasa Intelektual Indonesia, Edisi Pertama. Jakarta: Penerbit Melibas.

Suwarno, P. J. (1994). Hamengku Buwono IX dan sistem birokrasi pemerintahan Yogyakarta 1942-1974 sebuah tinjauan historis. Yogyakarta: Kanisius, hal. 37.

United Nations on Commission Human Rights, http:/www.ohchr.org/EN/HRBodies/CHR/Pages/CommissionOnHumanRights.aspx, diunduh pada 6 Februari 2017.

Undang-Undang Dasar Negara Republik Indonesia Tahun 1945.

Undang-Undang Republik Indonesia Nomor 30 Tahun 2014 Tentang Administrasi Pemerintahan.

Undang-Undang Republik Indonesia Nomor 28 Tahun 1999 Tentang Penyelenggaraan Negara Yang Bersih dan Bebas Dari Korupsi, Kolusi, dan Nepotisme.

Undang-Undang Republik Indonesia Nomor 2 Tahun 2012 tentang Pengadaan Tanah Bagi Pembangunan Untuk Kepentingan Umum.

Undang-Undang Republik Indonesia Nomor 23 Tahun 2014 tentang Pemerintahan Daerah.

Winarno, B. (2002). Teori dan proses kebijakan public. Jakarta: Media Pressindo. 